\title{
Intravascular lymphoma - The creepy crawler: A case series and brief literature review
}

\author{
Kainat Saleem ${ }^{1}$, Azadeh Nasrazadani ${ }^{1}$, Chaoyuan Kuang ${ }^{1}$, Vanya Jaitly ${ }^{1}$, Jonhan Ho ${ }^{1}$, \\ Anastasios Raptis ${ }^{1}$, Roy Smith ${ }^{1}$, and Craig Seaman ${ }^{1}$ \\ ${ }^{1} \mathrm{UPMC}$
}

July 19, 2021

\begin{abstract}
We present four cases of intravascular large B-cell lymphoma (IVLBCL), a rare malignancy with poor outcomes. The exclusive presence of lymphoma cells in blood vessels leads to a heterogenous presentation and poor diagnostic yield with traditional initial diagnostic tools. Timely diagnosis and treatment can lead to improved outcomes.
\end{abstract}

Intravascular lymphoma - The creepy crawler: A case series and brief literature review

Kainat Saleem ${ }^{1}$, Azadeh Nasrazadani ${ }^{*}$, Chaoyuan Kuang ${ }^{2 *}$, Vanya $\mathrm{Jaitly}^{3}$, Jonhan $\mathrm{Ho}^{4}$, Anastasios Raptis ${ }^{2}$, Roy Smith², Craig Seaman ${ }^{2}$

${ }^{1}$ Division of General Internal Medicine, Department of Medicine, University of Pittsburgh Medical Center, Pittsburgh, Pennsylvania

${ }^{2}$ Division of Hematology-Oncology, Department of Medicine, University of Pittsburgh Medical Center, Pittsburgh, Pennsylvania

${ }^{3}$ Division of Hematopathology, Department of Pathology, University of Pittsburgh Medical Center, Pittsburgh, Pennsylvania

${ }^{4}$ Division of Dermatopathology, Department of Pathology, University of Pittsburgh Medical Center, Pittsburgh, Pennsylvania

Correspondence: Kainat Saleem; 200 Lothrop Street, Suite G 100, UPMC Montefiore, Pittsburgh, PA 15213; email: saleemk@upmc.edu; Cellular: 224-770-1901; Fax: 412-692-4555

Declaration of interest: The authors do not have any interests to declare, financial or otherwise.

Ethics statement: This study was performed in accordance with the Declaration of Helsinki. This human study and its associated processes were approved by the University of Pittsburgh Institutional Review Board and the University of Pittsburgh Office of Research Informatics, academic affiliates of the University of Pittsburgh Medical Center. Adult participant consent was not required because the study was retrospective and posed minimal risk to the subjects. All identifying information that could be traced back to the subjects was removed from the manuscript. A HIPPA waiver was obtained from IRB.

\footnotetext{
Abstract

We present four cases of intravascular large B-cell lymphoma (IVLBCL), a rare malignancy with poor outcomes. The exclusive presence of lymphoma cells in blood vessels leads to a heterogenous presentation and poor diagnostic yield with traditional initial diagnostic tools. Timely diagnosis and treatment can lead to improved outcomes.
} 


\section{Key Clinical Message}

Intravascular B-cell lymphoma (IVLBCL) has a heterogenous presentation due to the exclusive presence of lymphoma cells in blood vessels and lack of lymphomatous aggregates. High clinical suspicion can lead to early recognition and improved outcomes.

Keywords: B-cell lymphoma, extranodal lymphoma, IVL, intravascular lymphoma, intravascular B-cell lymphoma

\section{Introduction}

IVLBCL is a rare form of extranodal diffuse large B-cell lymphoma with an incidence rate of 0.095 per $1,000,000^{1}$. Increased recognition of this entity has led to an increase in the number of reported cases over time. Three different subtypes of IVLBCL are identified: classical variant (more common in Western countries), hemophagocytic syndrome-associated (more common in Asian countries), and a cutaneous variant ${ }^{2}$. Herein, the natural history of IVLBCL is described for four patients, each with a unique presentation of the disease. A brief review of the available literature on this topic is additionally provided.

\section{Case description}

\section{Case 1}

A 69-year-old female was admitted with a 6-month history of episodic fevers, 50-lb weight loss, anemia, and cognitive decline. Prior to admission, she had undergone extensive workup for cognitive decline, including MRI brain, EEG, and CSF analysis for viral, bacterial, fungal, and tuberculous infections; no cause of her symptoms could be identified. Her fevers had been evaluated with a comprehensive rheumatological workup, which was inconclusive. Imaging of the chest, abdomen, and pelvis did not show any occult malignancies. Peripheral blood flow cytometry and bone marrow biopsy was unremarkable. Pertinent labs on presentation include WBC $10.3 \times 10^{9} / \mathrm{L}$, hemoglobin $9.6 \mathrm{~g} / \mathrm{dL}$, platelets $157 \times 10^{9} / \mathrm{L}$, total bilirubin $0.6 \mathrm{mg} / \mathrm{dL}$, ferritin $1432 \mathrm{ng} / \mathrm{mL}, \mathrm{LDH} 404 \mathrm{IU} / \mathrm{L}$, ESR $53 \mathrm{~mm} / \mathrm{hr}$, INR 1.5. Given her non-focal symptoms and lack of a definitive infectious or malignant etiology, intravascular lymphoma was suspected. Random deep skin biopsies were taken and showed several dilated blood vessels with sparse collections of large atypical lymphoid cells with irregular nuclei, prominent nucleoli, and moderately abundant cytoplasm. Cells were positive for CD20 and MUM1, and negative for CD10, BCL-2, and BCL-6. The patient urgently received one cycle of dose-reduced R-EPOCH (dose level -1) with GCSF support, which resulted in significant cognitive improvement over the next few weeks. The treatment course was complicated by neutropenic fever, recurrent hospital admissions, and functional decline. It was recommended that therapy be switched to mini-R-CHOP, but the patient's poor ECOG status allowed single-agent rituximab therapy only. Follow-up PET/CT showed no evidence of disease. The decision was made to stop therapy as single-agent rituximab was considered insufficient for maintaining remission. The patient was placed on observation for the recurrence of signs and symptoms. She was disease-free at the time of the last contact with the system.

\section{Case 2}

A 78-year-old female with CKD stage IV and active warfarin use for VTE was admitted with six weeks of progressive generalized weakness, lethargy, and a few months of functional decline. Pertinent labs on admission include: WBC $3.8 \times 10^{9} / \mathrm{L}$, hemoglobin $8.3 \mathrm{~g} / \mathrm{dL}$, platelets $55 \times 10^{9} / \mathrm{L}$, total bilirubin $0.7 \mathrm{mg} / \mathrm{dL}$, ESR $120 \mathrm{~mm} / \mathrm{hr}$, INR 3.2 , creatinine $5.5 \mathrm{mg} / \mathrm{dL}$, eGFR $9 \mathrm{~mL} / \mathrm{min} / 1.73 \mathrm{~m}^{2}$. Workup was initiated for kidney injury. Several days into admission, her labs worsened to WBC $1.4 \times 10^{9} / \mathrm{L}$, hemoglobin $5.5 \mathrm{~g} / \mathrm{dL}$, platelets 31 x $10^{9} / \mathrm{L}$, ferritin $1316 \mathrm{ng} / \mathrm{mL}$, LDH $2289 \mathrm{IU} / \mathrm{L}$, INR 3.4. Peripheral blood smear showed normal morphology of all cell lines. A bone marrow biopsy was planned; however, her overall condition deteriorated rapidly, and she went into shock and respiratory failure. She subsequently had a PEA arrest requiring brief CPR. After ROSC, she was found to be in DIC that was refractory to blood products. Supportive measures such as continuous hemodialysis and pressors were initiated but were ultimately unsuccessful and were followed by her passing. An autopsy showed extensive vascular involvement of all histological sections (bone marrow, liver, kidney, large bowel, pancreas) by large atypical malignant lymphoid cells. Cells were positive for CD20, 
BCL-2, scattered positive for CD5 and CD10, and negative for BCL-6 and MUM1. The cause of death was multiorgan failure secondary to systemic hemorrhage from coagulopathy due to intravascular lymphoma.

\section{Case 3}

A 70-year-old female was found to have incidental enlargement of the thyroid gland on a routine outpatient visit. Thyroid ultrasound showed multiple heterogeneous nodules in the right and left lobes and isthmus. No neck adenopathy was seen. Thyroid function tests were normal (TSH $0.73 \mathrm{mIU} / \mathrm{L}$, free T4 $1.25 \mathrm{ng} / / \mathrm{dL}$ ), and the patient was asymptomatic. Fine needle aspiration of the two largest thyroid nodules was done, and pathology showed scattered highly atypical epithelioid cells suspicious for carcinoma. The patient underwent total elective thyroidectomy for a definitive diagnosis. Pathology showed large pleomorphic B-cells in small vascular channels in both thyroid lobes. Cells were positive for CD10, CD5, BCL-6, and partially positive for MUM1. BCL-2 was negative. No primary thyroid malignancy was found. Staging PET/CT and MRI brain were negative for systemic involvement. CSF analysis was deferred given the lack of clinical and radiological evidence of CNS involvement. The patient continues to be monitored off chemotherapy with serial imaging and remains disease-free.

\section{Case 4}

A 63-year-old male on tacrolimus and mycophenolate mofetil (MMF) for prior renal transplant was admitted for a several-week history of episodic fevers. His prior workup, including cultures and serologies for viral infections, was negative. Pertinent labs at admission: WBC $2.1 \times 10^{9} / \mathrm{L}, \mathrm{Hb} 10.2 \mathrm{gm} / \mathrm{dL}$, platelets $60 \times 10^{9} / \mathrm{L}$, total bilirubin $0.9 \mathrm{mg} / \mathrm{dL}$, LDH $554 \mathrm{IU} / \mathrm{L}$, ESR $11 \mathrm{~mm} / \mathrm{hr}$. Peripheral blood smear showed moderate anisocytosis and normal WBC and platelet morphology. Bone marrow biopsy showed trilineage hematopoiesis with occasional large atypical lymphoid cells in small vessels. Cells were positive for CD20, CD79s, and CD5, and mostly negative for BCL-2, BCL-6, and CD10. Cytogenetic studies showed abnormal clones with structural rearrangements of chromosomes $3,5,9,10$, and 14 along with loss of 6q. Follow-up random skin biopsies showed rare, atypical intravascular B cells positive for CD20. EBER was negative. CT neck, chest, abdomen, and pelvis were negative for lymphadenopathy. CSF was negative for malignant cells. He received six cycles of R-CHOP with intrathecal methotrexate with the recovery of counts. MMF was discontinued at the time of diagnosis. Follow-up PET/CT did not show any evidence of disease. Post-treatment bone marrow biopsy was negative for any morphological or immunophenotypic evidence of lymphoma. The patient continues to be in remission on follow-up.

\section{Discussion}

In the Western world, IVLBCL is a disease of the elderly, with the median age of diagnosis being 70 years ${ }^{1,2}$. It is classically poorly understood and appreciated as an aggressive malignancy with dismal outcomes. In historical cohorts, most cases were diagnosed postmortem, although we are increasingly learning more about this elusive disease. IVLBCL is characterized by the exclusive growth of malignant cells in medium-sized blood vessels. Figure 1 is a composite of photographs of our patients' biopsy specimens, which shows the presence of lymphoma cells within the vasculature of affected organs (skin, liver, thyroid, and bone marrow). As described in our patients, distinct lymphomatous masses are usually not seen ${ }^{3}$. Symptoms are caused by occlusion of blood vessels, and thus extravascular infiltration of tissues does not occur. IVLBCL commonly presents with fever, weight loss, and deterioration of functional status, which confounds early diagnosis due to the generality of these symptoms. Involvement of specific organ vasculature such as the G.I. tract, endocrine organs, or lungs can produce focal symptoms ${ }^{4,5}$. The heterogeneity of its presentation further complicates the clinicians' ability to reach this diagnosis. Traditional diagnostic methods such as PET/CT scans can be inconclusive given the exclusive presence of lymphoma cells inside the vessels. However, focal organ involvement, including bone marrow in cases with heavy infiltration of blood vessels, may be visualized ${ }^{6}$. In patients with neurological signs and symptoms, MRI brain can show non-specific changes in white matter ${ }^{4,6}$. As detailed with our patient cohort, bone marrow biopsy, random skin biopsies, or biopsies of specific organs in cases with focal symptoms compose the basis of effective diagnosis ${ }^{7}$.

IVLBCL has a complex pathophysiology that is not well understood. Malignant cells are invariably positive 
for CD20; however, T-cells markers such as CD5 can be positive as well. Most cells exhibit a non-germinal center phenotype (BCL-2 and MUM1 positive, CD10 and BCL-6 negative) ${ }^{2,8}$. Loss of ICAM-1 and integrin $\beta 1$ expression has been described as a reason for the lack of tumor invasion into surrounding tissues ${ }^{7}$. Cytogenetics is complex, and implicit genetic mutations have not been identified. An interesting finding in two of our cases was the active use of immunosuppression at diagnosis. In case 2, our patient was on adalimumab for inverse psoriasis, while the patient in case 4 was on tacrolimus/MMF for renal transplant. Withdrawal of immunosuppression was used as an adjunct to chemo-immunotherapy in case 4, which resulted in complete remission of the disease. This raises the question as to whether IVLBCL shares a common underlying mechanism with post-transplant lymphoproliferative disorder (PTLD). It remains unclear if any other comorbidities play a significant role in IVLBCL development or prognosis. Patient comorbidities are listed in detail in table 1.

Despite increasing awareness, IVLBCL remains a rare disorder, and prospective studies regarding treatment regimens and outcomes are lacking. Two out of our four patients had good outcomes with anthracycline-based therapy. In case 1, our patient achieved remission with only one dose of dose-reduced R-EPOCH despite being diagnosed six months from symptoms onset. This case suggests a potentially more indolent cohort that may benefit from aggressive chemo-immunotherapy despite a delayed diagnosis. Outcomes of cases 1 and 4 are similar to reports in the literature, suggesting a median overall survival of 105 months and 5-year survival of $53 \%$ with the use of anthracycline-based regimens in IVLBCL ${ }^{6}$. The addition of rituximab has been associated with improved rates of complete remission and progression-free survival ${ }^{8,9}$. These outcomes are similar to those seen in DLBCL NOS ${ }^{1}$. Case 1 contrasts with case 2, where the patient presented with a similar duration of symptoms but rapidly developed malignancy-related complications and died. The time course of this case coincides with the historical portrayal of IVLBCL as an aggressive and fatal disease. The disease is thought to have been too far advanced in this case to allow timely receipt of cancer-directed therapy. Case 3 demonstrated focal end-organ involvement with IVLBCL and with remission achieved upon resection. This patient continued to be in remission despite not receiving any systemic therapy. Maintenance of remission in this case with simple resection of the involved organ may represent a novel approach to managing patients with single organ involvement with IVLBCL. This approach is, however, not an option for more commonly observed bone marrow involving variants. Stem cell transplant after initial induction remains a treatment option, although cannot be offered to many patients due to advanced age at diagnosis and poor ECOG status ${ }^{4}$. Despite the vast variations in presentation and natural histology of the disease even noted within our case series, the observed potential for improved outcomes hinges on timely diagnosis and early initiation of systemic therapies when indicated.

\section{Conclusion}

Intravascular B-cell lymphoma has traditionally been associated with an aggressive course and poor outcomes. Recent efforts to increase awareness and improved insight into the disease have led to increased identification of this disorder. However, it remains an elusive diagnosis due to heterogeneity in presentation. The development of IVLBCL in two of our patients on active immunosuppression could point towards an underlying disease mechanism similar to that seen in the development of post-transplant lymphoproliferative disorder. Traditional preliminary diagnostic modalities such as imaging are usually inconclusive, given the paucity of lymphomatous aggregates. A bone marrow biopsy, random skin biopsies, or a focal organ biopsy in appropriate cases is required for diagnosis. Nevertheless, a timely diagnosis requires a high clinical suspicion. Early initiation of aggressive anthracycline-based therapy with rituximab is associated with improved

outcomes. Novel treatment approaches such as end-organ resection, if the disease is limited to a single organ such as thyroid or kidney, can potentially induce remission without the need for systemic therapy.

\section{Author contribution}

Kainat Saleem: investigation, data curation, writing - original draft, visualization

Azadeh Nasrazadani: conceptualization, investigation, writing - reviewing and editing

Chaoyuan Kuang: conceptualization, writing - reviewing and editing 
Vanya Jaitly: investigation, data curation

Jonhan Ho: investigation, data curation

Anastasios Raptis: writing - reviewing and editing

Roy Smith: writing - reviewing and editing

Craig Seaman: writing - reviewing and editing, supervision.

*A.Z. and C.K. were equal contributors to the study and should both be considered second authors.

\section{Acknowledgments}

The authors would like to thank Dr. Konstantinos Lontos for his helpful suggestions throughout the study. The authors would also like to thank the University of Pittsburgh Medical Center for providing them with the resources to conduct this study.

\section{References}

1. Rajyaguru DJ, Bhaskar C, Borgert AJ, Smith A, Parsons B. Intravascular large B-cell lymphoma in the United States (US): a population-based study using Surveillance, Epidemiology, and End Results program and National Cancer Database*. Leuk Lymphoma . 2017;58(9):2080-2088. doi:10.1080/10428194.2017.1287363

2. Sukswai N, Lyapichev K, Khoury JD, Medeiros LJ. Diffuse large B-cell lymphoma variants: an update. Pathology . 2020;52(1):53-67. doi:10.1016/j.pathol.2019.08.013

3. Yamada E, Ishikawa E, Watanabe $\mathrm{R}$, et al. Random Skin Biopsies Before Brain Biopsy for Intravascular Large B-Cell Lymphoma. World Neurosurg . 2019;121:e364-e369. doi:https://doi.org/10.1016/j.wneu.2018.09.110

4. Shimada K, Kinoshita T, Naoe T, Nakamura S. Presentation and management of intravascular large B-cell lymphoma. Lancet Oncol . 2009;10(9):895-902. doi:https://doi.org/10.1016/S1470-2045(09)70140-8

5. Brunet V, Marouan S, Routy J-P, et al. Retrospective study of intravascular large B-cell lymphoma cases diagnosed in Quebec: A retrospective study of 29 case reports. Medicine (Baltimore) . 2017;96(5):e5985. doi:10.1097/MD.0000000000005985

6. Matsue K, Abe Y, Narita K, et al. Diagnosis of intravascular large B cell lymphoma: novel insights into clinicopathological features from 42 patients at a single institution over 20 years. $\mathrm{Br} \mathrm{J} \mathrm{Haematol}$. 2019;187(3):328-336. doi:10.1111/bjh.16081

7. Sitthinamsuwan P, Chinthammitr Y, Pattanaprichakul P, Sukpanichnant S. Random skin biopsy in the diagnosis of intravascular lymphoma.J Cutan Pathol . 2017;44(9):729-733. doi:https://doi.org/10.1111/cup.12984

8. Ponzoni M, Campo E, Nakamura S. Intravascular large B-cell lymphoma: a chameleon with multiple faces and many masks. Blood . 2018;132(15):1561-1567. doi:10.1182/blood-2017-04-737445

9. Shimada K, Matsue K, Yamamoto K, et al. Retrospective Analysis of Intravascular Large B-Cell Lymphoma Treated With Rituximab-Containing Chemotherapy As Reported by the IVL Study Group in Japan. J Clin Oncol . 2008;26(19):3189-3195. doi:10.1200/JCO.2007.15.4278

Table 1: Overview of patients. Abbreviations: DOD, dead of disease; MMF, mycophenolate mofetil; MTX, methotrexate; R-CHOP, rituximab + cyclophosphamide/doxorubicin/vincristine/prednisone; R$\mathrm{EPOCH}$, rituximab + etoposide/prednisone/vincristine/cyclophosphamide/doxorubicin; NED, no evidence of disease; VTE, venous thromboembolism 


\begin{tabular}{|c|c|c|c|c|c|c|c|c|}
\hline Case & $\begin{array}{l}\text { Age at } \\
\text { diagnosis } \\
\text { (years) }\end{array}$ & Sex & $\begin{array}{l}\text { ECOG } \\
\text { status at } \\
\text { diagnosis }\end{array}$ & $\begin{array}{l}\text { Comorbid } \\
\text { at } \\
\text { diagnosis }\end{array}$ & $\begin{array}{l}\text { Time- } \\
\text { lapse } \\
\text { between } \\
\text { the onset } \\
\text { tios symp- } \\
\text { toms and } \\
\text { diagnosis }\end{array}$ & $\begin{array}{l}\text { Biopsy } \\
\text { site for } \\
\text { diagnosis }\end{array}$ & $\begin{array}{l}\text { Treatment } \\
\text { received }\end{array}$ & $\begin{array}{l}\text { Last } \\
\text { known } \\
\text { status of } \\
\text { the } \\
\text { disease }\end{array}$ \\
\hline 1 & 69 & $\mathrm{~F}$ & 3 & $\begin{array}{l}\text { Superficial } \\
\text { recurrent } \\
\text { melanoma } \\
\text { of nose } \\
\text { status } \\
\text { post } \\
\text { excision } \\
\text { Thyroid } \\
\text { cancer } \\
\text { thirty } \\
\text { years } \\
\text { prior, } \\
\text { status } \\
\text { post } \\
\text { thyroidec- } \\
\text { tomy } \\
\text { Hyperten- } \\
\text { sion } \\
\text { Anemia of } \\
\text { chronic } \\
\text { disease }\end{array}$ & $\begin{array}{l}\sim 6 \\
\text { months }\end{array}$ & Skin & $\begin{array}{l}\text { R-EPOCH } \\
(-1) \text { x } 1 \\
\text { cycle } \\
\text { Then: } \\
\text { Single- } \\
\text { agent } \\
\text { rituximab } \\
\text { weekly x } 4 \\
\text { doses q6 } \\
\text { months. } \\
\text { One cycle } \\
\text { Then: } \\
\text { Single- } \\
\text { agent } \\
\text { rituximab, } \\
\text { one dose } \\
\text { q2 months } \\
\text { for two } \\
\text { months }\end{array}$ & NED \\
\hline
\end{tabular}




\begin{tabular}{|c|c|c|c|c|c|c|c|c|}
\hline Case & $\begin{array}{l}\text { Age at } \\
\text { diagnosis } \\
\text { (years) }\end{array}$ & Sex & $\begin{array}{l}\text { ECOG } \\
\text { status at } \\
\text { diagnosis }\end{array}$ & $\begin{array}{l}\text { Comorbidi } \\
\text { at } \\
\text { diagnosis }\end{array}$ & $\begin{array}{l}\text { Time- } \\
\text { lapse } \\
\text { between } \\
\text { the onset } \\
\text { tiof symp- } \\
\text { toms and } \\
\text { diagnosis }\end{array}$ & $\begin{array}{l}\text { Biopsy } \\
\text { site for } \\
\text { diagnosis }\end{array}$ & $\begin{array}{l}\text { Treatment } \\
\text { received }\end{array}$ & $\begin{array}{l}\text { Last } \\
\text { known } \\
\text { status of } \\
\text { the } \\
\text { disease }\end{array}$ \\
\hline 2 & 78 & $\mathrm{~F}$ & 3 & $\begin{array}{l}\text { CKD } \\
\text { stage IV } \\
\text { secondary } \\
\text { to hyper- } \\
\text { tension } \\
\text { and MTX } \\
\text { use } \\
\text { Inverse } \\
\text { psoriasis } \\
\text { treated } \\
\text { with adal- } \\
\text { imumab } \\
\text { Recurrent } \\
\text { VTE } \\
\text { Anticoag- } \\
\text { ulation } \\
\text { with } \\
\text { warfarin } \\
\text { Hypothy- } \\
\text { roidism } \\
\text { Pancreatic } \\
\text { neuroen- } \\
\text { docrine } \\
\text { neoplasia } \\
\text { ten years } \\
\text { prior, } \\
\text { status } \\
\text { post } \\
\text { definitive } \\
\text { resection }\end{array}$ & $\begin{array}{l}\sim 6 \\
\text { months }\end{array}$ & Autopsy & None & DOD \\
\hline
\end{tabular}




\begin{tabular}{|c|c|c|c|c|c|c|c|c|}
\hline Case & $\begin{array}{l}\text { Age at } \\
\text { diagnosis } \\
\text { (years) }\end{array}$ & Sex & $\begin{array}{l}\text { ECOG } \\
\text { status at } \\
\text { diagnosis }\end{array}$ & $\begin{array}{l}\text { Comorbidi } \\
\text { at } \\
\text { diagnosis }\end{array}$ & $\begin{array}{l}\text { Time- } \\
\text { lapse } \\
\text { between } \\
\text { the onset } \\
\text { tiof symp- } \\
\text { toms and } \\
\text { diagnosis }\end{array}$ & $\begin{array}{l}\text { Biopsy } \\
\text { site for } \\
\text { diagnosis }\end{array}$ & $\begin{array}{l}\text { Treatment } \\
\text { received }\end{array}$ & $\begin{array}{l}\text { Last } \\
\text { known } \\
\text { status of } \\
\text { the } \\
\text { disease }\end{array}$ \\
\hline 3 & 70 & $\mathrm{~F}$ & 1 & $\begin{array}{l}\text { Type } 2 \\
\text { diabetes } \\
\text { AKI } \\
\text { requiring } \\
\text { transient } \\
\text { hemodial- } \\
\text { ysis two } \\
\text { years prior } \\
\text { Stage III } \\
\text { CKD } \\
\text { secondary } \\
\text { to diabetic } \\
\text { nephropa- } \\
\text { thy CAD } \\
\text { status } \\
\text { post PCI }\end{array}$ & $\begin{array}{l}\text { Incidental } \\
\text { finding }\end{array}$ & Thyroid & $\begin{array}{l}\text { Total } \\
\text { thyroidectomy }\end{array}$ & $\begin{array}{l}\text { NED } \\
\text { ly }\end{array}$ \\
\hline 4 & 63 & $\mathrm{M}$ & 2 & $\begin{array}{l}\text { ESRD } \\
\text { secondary } \\
\text { to } \\
\text { ADPKD } \\
\text { Status- } \\
\text { post renal } \\
\text { transplant } \\
\text { Immuno- } \\
\text { suppres- } \\
\text { sion with } \\
\text { tacrolimus } \\
\text { and MMF }\end{array}$ & 1 month & $\begin{array}{l}\text { Bone } \\
\text { marrow }\end{array}$ & $\begin{array}{l}\text { Six cycles } \\
\text { of } \\
\text { R-CHOP } \\
\text { with } \\
\text { intrathecal } \\
\text { MTX } \\
\text { Discontin- } \\
\text { uation of } \\
\text { MMF }\end{array}$ & NED \\
\hline
\end{tabular}

Figure 1: Case 1, Small vessels in the subcutis of thigh skin feature atypical hyperchromatic lymphoid cells in the lumen (Panel A, hematoxylin and eosin stain, original magnification $\times 400$ ) which are CD20 positive (Panel B, original magnification $\times 400$ ); Case 2, Liver sinusoids filled and expanded by large atypical B-cells (Panel C, hematoxylin and eosin stain, original magnification $\times 400$ ); Case 3, Small vessels in the thyroid are filled with large pleomorphic B-cells (Panel D, hematoxylin and eosin stain, original magnification $\times 400$ ) which are CD20 positive (Panel E, original magnification $\times 200$ ); Case 4, CD20 stain in the bone marrow biopsy highlighting occasional atypical B-cells in the vessels (Panel F original magnification $\times 400$ ) 


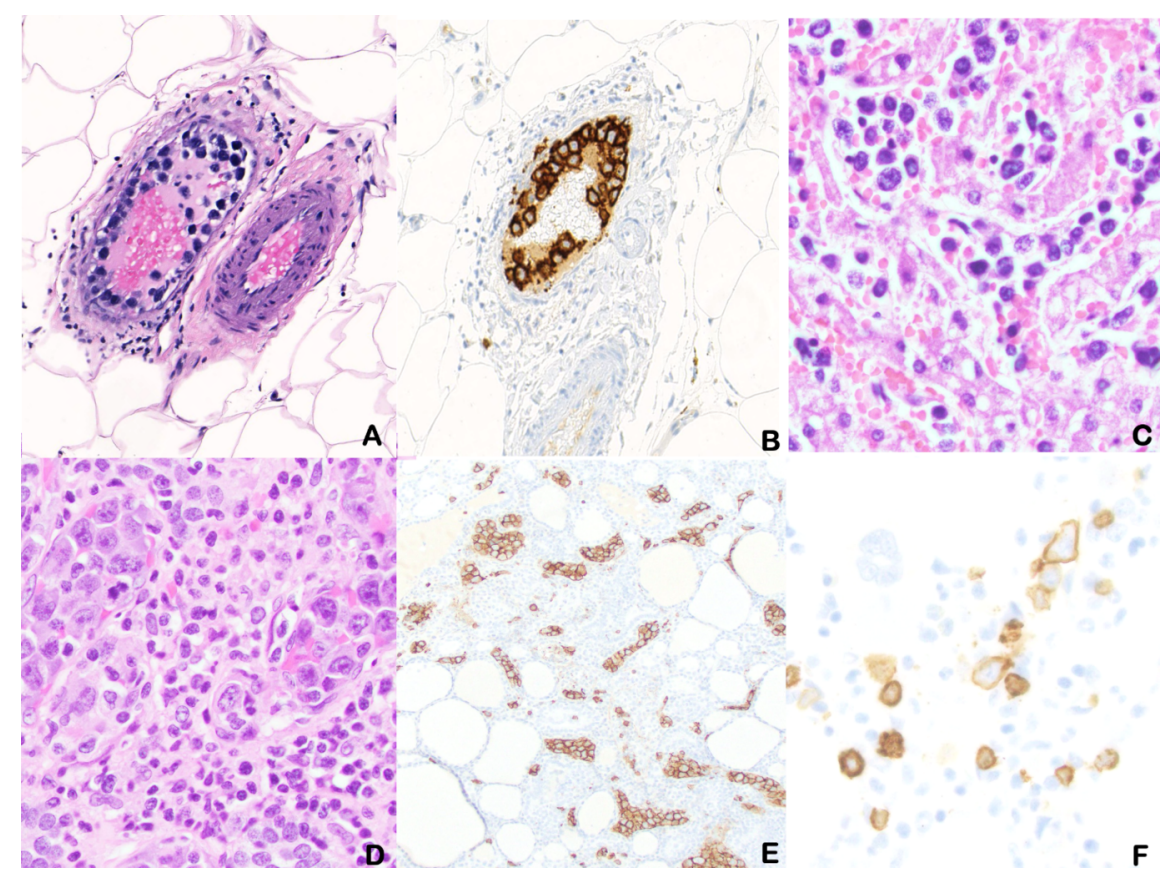

